NBER WORKING PAPER SERIES

\title{
WHO LEAVES? THE OUTMIGRATION OF THE FOREIGN-BORN
}

George J. Borjas

Bent Bratsberg

Working Paper No. 4913

\section{NATIONAL BUREAU OF ECONOMIC RESEARCH 1050 Massachusetts Avenue \\ Cambridge, MA 02138 \\ November 1994}

We are grateful to Robert Warren for providing us with a number of unpublished INS statistics, and to two anonymous referees for helpful suggestions. This research was supported by the National Science Foundation. This paper is part of NBER's research program in Labor Studies. Any opinions expressed are those of the authors and not those of the National Bureau of Economic Research.

(C) 1994 by George J. Borjas and Bernt Bratsberg. All rights reserved. Short sections of text, not to exceed two paragraphs, may be quoted without explicit permission provided that full credit, including $\odot$ notice, is given to the source. 
NBER Working Paper \#4913

November 1994

\title{
WHO LEAVES? THE OUTMIGRATION \\ OF THE FOREIGN-BORN
}

\begin{abstract}
This paper analyzes the return migration of foreign-born persons in the United States. We argue that return migration may have been planned as part of an optimal life cycle residential location sequence. Return migration also occurs because immigrants based their initial migration decision on erroneous information about opportunities in the United States. The study uses the 1980 Census and administrative data from the Immigration and Naturalization Service. Immigrants tend to return to wealthy countries which are not too far from the United States. Moreover, return migration accentuates the type of selection characterizing the immigrant population left in the United States.
\end{abstract}

George J. Borjas

Department of Economics, 0508

University of California, San Diego

9500 Gilman Drive

La Jolla, CA 92093

and NBER

\author{
Bernt Bratsberg \\ Department of Economics \\ Waters Hall \\ Kansas State University \\ Manhattan, KS 66506
}




\section{WHO LEAVES? THE OUTMIGRATION OF THE FOREIGN-BORN}

\section{George J. Borjas and Bernt Bratsberg}

\section{Introduction}

Migration decisions are reversible. Studies of internal migration within the United States indicate that recent migrants have a high probability of returning to their origin or of moving on to other locations (DaVanzo, 1973; Fields, 1979). Studies of international migration flows also suggest the presence of large numbers of return migrants. Warren and Peck (1980) and Warren and Kraly (1985) estimate that perhaps 30 percent of the foreign-born persons in the United States leave the country within a decade or two after their arrival. ${ }^{1}$

The fact that large numbers of immigrants choose not to remain in the United States has important implications. In fact, much of the empirical evidence about the economic impact of immigration reported in the literature is contaminated by the nonrandom nature of the outmigration decision. Consider, for instance, the cross-section finding that recently arrived immigrants have lower earnings than earlier immigrants. Although this result can be interpreted as evidence of rapid economic assimilation, it can also be explained through outmigration behavior. In particular, suppose that immigrants who fail in the U.S. labor market leave the country. In any given cross-section, early immigrant waves have been "weeded out," and have higher average earnings than the more recent waves (which include future outmigrants). ${ }^{2}$

\footnotetext{
${ }^{1}$ It is unknown if these outmigrants are retum migrants (in the sense that they are returning to their country of birth), or if they are remigrating to a third country. Throughout this paper, therefore, we use the terms return migrants and outmigrants as synonymous, even though we do not know the final destination of these flows. For additional estimates of return migration rates in the immigrant population, see Jasso and Rosenzweig (1982) and Lam (1987).

2It is important to note that the biases introduced by nonrandom outmigration remain even if immigrants waves are 1racked across Censuses (as in Borjas, 1985). Later censuses enumerate only
} 
Despite the practical importance of return migration, little is known either conceptually or empirically about the selection process guiding the outmigration decision of the foreign-born. Two recent studies, by Borjas (1989) and Jasso and Rosenzweig (1988), begin to address these issues. In the Borjas study, outmigration behavior is inferted from sample attrition in a longitudinal data set of foreign-born scientists and engineers. He finds that the least successful scientists and engineers are most likely to drop out from the sample, and concludes that the outmigration process is one in which "failures" leave the United States. In contrast, Jasso and Rosenzweig observe the naturalization decision of immigrants, and infer that those who do not naturalize are most likely to leave the country. In their study, it is the most skilled workers who do not naturalize, and are most likely to be outmigrants. ${ }^{3}$

This paper presents a conceptual and empirical analysis of the retum migration behavior of foreign-bom persons in the United States. We argue that outmigration can arise for two reasons. First, the retum migration may have been planned as part of an optimal life-cycle residential location sequence, wherein some immigrants migrate to the United States for a few years, accumulate financial resources or other types of capital, and then retum to the source country. Alternatively, return migration occurs because immigrants based their initial migration decision on erroneous information about economic opportunities in the United States.

those immigrants who reside in the United States, and hence much of what is measured as assimilation by the tracking procedure may be due to the changing composilion of the immigrant cohort.

${ }^{3}$ A study by Lam (1987) also attempts to analyze outmigration behavior, and presents some estimates of outmigration rates, but does not address the questions about the self-selection underlying the phenomenon. Tunali (1986) addresses selection issues with respect to the remigralion process of persons in Turkey. Finally, Pessino (1991) constructs a model of remigration based on the hypothesis that outmigration can be mainly attributed to forecasting errors. 
The empirical analysis relies on the 1980 Public Use Sample of the U.S. Census, 'and on administrative microdata from the Immigration and Naturalization Service (INS). By combining these data, as well as by bringing in outside information on such factors as the number of illegal aliens, we calculate outmigration rates for immigrants from 70 source countries. These outmigration rates indicate that immigrants tend to retum to wealthy countries that are not too distant from the United States. In addition, the empirical evidence suggests that the retum migration process accentuates the type of selection characterizing the immigrant population left in the United States.

\section{Theory}

There are two alternative approaches to modeling the retum migration decision. The first views retum migration as part of an optimal residential location plan over the life cycle (as in the occupational mobility model of Rosen, 1972). In other words, some workers consciously decide to immigrate to the United States for a few years, and then retum to their home countries after accumulating sufficiently large levels of capital or wealth. Alternatively, retum migration flows may result from "mistakes" in the initial migration decision. Potential migrants in the source country are uncerain about the economic conditions they will face in the United States. As long as return migration costs are relatively low, workers who experience worse-than-expected outcomes in the United States may wish to retum to their home country.

We begin by presenting a model that incorporates both motives for return migration. Suppose individuals originate in country 0 and consider the possibility of immigrating, either 
temporarily or permanently, to country 1 (for concreteness, the United States). The log earnings distributions in the source country and in the United States are described by: ${ }^{4}$

$$
\begin{aligned}
& w_{0}=\mu_{0}+\eta \nu, \\
& w_{1}=\mu_{1}+\nu+\varepsilon,
\end{aligned}
$$

where $\mu_{0}$ is the mean income in the source country, and $\mu_{i}$ is the mean income that would be observed if all persons in the source country migrated to the United States. The random variables $\nu$ and $\varepsilon$ measure deviations from mean incomes, have zero means and finite variances, and are assumed to be independent. We also assume that $v$ is known to the individual, while $\varepsilon$ remains unknown unless the individual migrates to the United States. We interpret $v$ as reflecting ability or skills that are transferable across countries, while $\varepsilon$ reflects an uncertain component (perhaps due to misinformation or luck) in U.S. earnings. The parameter $\eta$ can be interpreted as the rate of return to skills in the source country relative to that in the United States.

Upon arrival to the United States, the immigrant makes a draw from the known density $g(\varepsilon)$, and if the value of the random draw is sufficiently negative chooses to return to the source country immediately. The immigrant also knows, however, that a temporary stay in the United States might improve the economic options he faces in the source country. The simplest way of

\footnotetext{
The model presented below generalizes the Roy model framework (Roy, 1951; Borjas, 1987) to include the option of return migration.

${ }^{3}$ Note that the model assumes a perfect correlation between the skill components of eamings in the two countries (i.e., between $v$ and $\eta v$ ). Obviously, this assumption restricts the types of migration flows that can be generated. Borjas (1987) shows that if the correlation coefficient were sufficiently small or negative, the migration flow would resemble a refugee sorting: The immigrant flow is then composed of persons who do badly in the source country, but who have skills which are useful in the United States.
} 
modeling the gains to the immigrant's investment is to assume that after spending a fraction $\pi$ of the working life in the United States, immigrants can increase their earnings in the source country by $\kappa$ percent. We assume that the parameter $\pi$ is constant, and that the individual's temporary stay in the United States, if it occurs at all, occurs at the beginning of the working life. ${ }^{6}$

Workers in the source country, therefore, have an additional option: residing in the United States for a fraction of the working life, followed by a permanent return to the source country. Ignoring discounting and using a first-order approximation, the log earnings associated with this choice are given by:

$$
w_{10}=\pi w_{1}+(1-\pi)\left(w_{0}+\kappa\right)
$$

We assume that the (percentage) gain to a temporary stay in the United States, $\kappa$, is constant among individuals. ${ }^{7}$

Workers choose the sequence of residential choices that maximizes their expected earnings, net of migration and remigration costs. Let $M$ be a "time-equivalent" measure of the costs of migrating to the United States $\left(M=C_{m} / w_{0}\right.$, where $C_{m}$ are the dollar costs of migration); $R$ be a time-equivalent measure of the costs of remigrating to the source country $\left(R=C_{\mathrm{r}} / w_{0}\right.$, where $C_{r}$ are the dollar costs of remigration). Further, assume that the time-equivalent costs of migration and remigration $\left(M\right.$ and $R$ ) are constant in the population. ${ }^{8}$

\footnotetext{
${ }^{6} \mathrm{~A}$ more general model would allow for the endogeneity of the length of time spen1 in the United Stales. ${ }^{7}$ Most of our findings are unaffected by a correlation belween $v$ and $k$ as long as this correlation is not excessive.

${ }^{8}$ I1 is easy to generalize the model to allow for variable migration costs. The qualitative nature of the results does nol change as long as the correlation between migration costs and $v$ is not excessive.
} 
Assuming risk neutrality, a person migrates to the United States if:

$$
\max \left[E w_{1}-M, E w_{10}-M-R\right]>w_{0}
$$

and a person migrates to the United States and then returns to the source country if:

$$
\max \left[E w_{1}-M, E w_{10}-M-R\right]>w_{0} \text { and } \max \left[w_{0}-R, w_{10}-R\right]>w_{1}
$$

Equation (4) states that a person in the source country migrates if either the expected wage from permanently migrating to the United States, or the expected wage from "investing" in a short stay in the United States exceeds the wage in the source country, net of the relevant migration and remigration costs. Equation (5) states that the sample of return migrants is generated from the subsample of persons who were migrants in the first place, and who have better opportunities in the source country (either in terms of $w_{0}$ or $w_{10}$ ) than the actual income available in the United States $\left(w_{1}\right)^{9}$

For the investment motive to be relevant for return migration, we need to assume: ${ }^{10}$

${ }^{9}$ We do not distinguish between persons who outmigrate immediately upon making a draw from the density $g(\varepsilon)$, and persons who remain in the United States for a fraction $\pi$ of the work cycle and then retum to the source country.

${ }^{10}$ This condition is necessary if anyone is to migrate to the Uniled States as pant of a planned life-cycle mobility pattern which includes remigration to the source country. To see why, note that for a worker to expect to retum to his source country, it must be the case that $E_{w_{10}}-M-R>E_{w_{1}}-M$ and $E_{w_{10}}-M-R$ $>w_{0}$. The first of these conditions implies that:

$$
(1-\eta) v<\mu_{0}-\mu_{1}+\kappa-\frac{R}{1-\pi},
$$

while the second condition implies: 
(6)

$$
\kappa>M+\frac{R}{1-\pi}
$$

In effect, the returns to spending a fraction of the working life in the United States must be sufficiently greater than the expected costs of migrating to and from the United States. Using this condition to compare the terms inside the $\max (\cdot)$ expressions in equations (4) and (5) generates the following equilibrium sorting of persons among alternatives:

(7) Stay in Source Country:

$$
(1-\eta) v \leq\left(\mu_{0}-\mu_{1}+\kappa\right)+\frac{M+R-\kappa}{\pi}
$$

(8) Migrate to United States: $\quad(1-\eta) v>\left(\mu_{0}-\mu_{1}+\kappa\right)+\frac{M+R-\kappa}{\pi}$,

(9) Return to Source Country: $\left(\mu_{0}-\mu_{1}+\kappa\right)+\frac{M+R-\kappa}{\pi}<(1-\eta) \nu<\left(\mu_{0}-\mu_{1}+\kappa\right)-\frac{R}{1-\pi}-\varepsilon$.

It is instructive to examine the characteristics of the migration flows when the distribution $g(\varepsilon)$ degenerates at $\varepsilon=0$, so that there is no uncertainty in the migration decision. Return migration can then only arise because a temporary stay in the United States increases the worker's

$$
(l-\eta) v>\mu_{0}-\mu_{1}+\kappa+\frac{M+R-\kappa}{\pi} .
$$

Combining these two conditions yields the restriction given by equation (6) in the text. 
earnings in the source country. The implications of the sorting summarized by equations (7)-(9) are illustrated in Figure 1 for the case where $\eta<1$, and in Figure 2 for the case where $\eta>1$.

Suppose initially that $\eta<1$. The immigrant flow is positively selected (i.e., it is composed of workers with higher-than-average skills). Figure 1 aiso shows that the retum migrant flow is composed of the least skilled immigrants. Intuitively, it is the highly skilled who gain the most by residing in the United States. The most skilled in this self-selected sample will wish to remain in the United States even if their economic opportunities improve in the source country. The leastskilled persons in this sample are the "marginal" immigrants. They are most responsive to changing economic conditions in the source country, and they will become return migrants in order to collect the returns on their investment.

Suppose instead that $\eta>1$. The immigrant flow is now composed of workers of below-average skills. Because the rate of return to skills is higher in the source country, the most skilled have little incentive to immigrate to the United States. As Figure 2 shows, even though the immigrant flow is relatively unskilled, it is the most skilled in this self-selected sample who find it optimal to become retum migrants. Intuitively, workers with the lowest skill levels find it optimal to reside in the United States, regardless of whether or not there are gains to be made by migrating back to the source country. The sample of return migrants will be composed of marginal immigrants, who in this case happen to be relatively more skilled than the typical immigrant.

Therefore, the return migration process intensifies the selection that characterizes the immigrant population in the United States. Because it is the marginal immigrants who leave, the immigrants who remain in the United States are the "best of the best" if there is positive selection, and the "worst of the worst" if there is negative selection. 
The conditional probability of retum migration, $q$, equals:

(10)

$$
q=\frac{\operatorname{Pr}\left(\left(\mu_{0}-\mu_{1}+\kappa\right)+\frac{M+R-\kappa}{\pi}<(l-\eta) \nu<\left(\mu_{0}-\mu_{1}+\kappa\right)-\frac{R}{1-\pi}\right)}{\operatorname{Pr}\left((1-\eta) \nu>\left(\mu_{0}-\mu_{1}+\kappa\right)+\frac{M+R-\kappa}{\pi}\right)}
$$

The qualitative effects of the various exogenous parameters on this probability are given by:

$$
\frac{\partial q}{\partial M}<0, \frac{\partial q}{\partial R}<0, \quad \frac{\partial q}{\partial x}>0
$$

In addition, if the density function of skills $f(v)$ is log-concave (see Heckman and Honoré, 1990), we obtain:

$$
\frac{\partial q}{\partial \mu_{0}}>0, \frac{\partial q}{\partial \eta}>0 \text { if } \eta<1, \frac{\partial q}{\partial \eta}<0 \text { if } \eta>1
$$

The derivatives in (11) indicate that the retum migration rate (the proportion of U.S. immigrants who leave the country) depends negatively on migration costs, $M$ and $R$. In addition, it is easy to show that if both $M$ and $R$ are increasing functions of a common variable $D$, such as distance, the derivative $\partial q / \partial D$ is negative. The outmigration rate also depends positively on $k$. If the earnings distributions are log-concave, a number of additional implications can be derived. For instance, the outmigration rate depends positively on mean income in the source 
country. "Return migrants would rather return to rich than to poor countries. Further, the outmigration rate is first an increasing function and then a decreasing function of $\eta$. Intuitively, the larger the difference between the rates of return to skills in the source country and the United States, the more that immigrants have to gain by staying in the United States, and the lower the outmigration rate.

The empirical analysis presented below indicates that our estimated return migration rates differ across source countries in ways that are generally consistent with these theoretical implications. Perhaps the most novel implication of the theory, however, is that return migration accentuates the type of selection that originally characterized the immigrant flow. Obviously, this result could be directly tested by comparing the earnings of the return migrants with those of the permanent immigrants, and determining if the differences between the two groups vary systematically among source countries according to the parameter $\eta$. Unfortunately, currently available data do not generally allow this type of systematic analysis. Instead, we will use an indirect implication of the theory to test its predictive power. In particular, Figures 1 and 2 indicate that holding constant the fraction of the source country's population that migrates to the United States, larger outmigration rates are associated with higher mean earnings for immigrants remaining in the United States if there is positive selection, and with lower mean earnings if there is negative selection.

As noted earlier, return migration can also arise as immigrants attempt to correct mistakes in the initial migration decision. As shown in the Appendix, allowing for uncertainty in the

\footnotetext{
"The prediction that $\partial g / \partial \mu_{0}>0$ is not affected by the possibility that an increase in $\mu_{0}$ also increases $\mu_{1}$ (presumably because skills are more easily uransferable across advanced economies), as long as $\partial \mu_{1} / \partial \mu_{0}$ $<1$.
} 
migration decision introduces a number of complexities which require additional restrictions on the joint density $h(\nu, \varepsilon)$. Nevertheless, the analysis suggests that both the human capital and the uncertainty models lead to the same key insight: Return migration intensifies the selection that characterized the original immigrant flow. Given this similarity in the implications of the two models and the scarcity of data on retum migration flows, it is unlikely that a simple test can be devised to distinguish between the competing hypotheses.

III. Data

We begin the empirical analysis by briefly describing the construction of our measures of outmigration rates for a large number of source countries. A detailed discussion of the data and the sensitivity of the estimates to alternative assumptions is given in Bratsberg (1991).

A generic definition of the outmigration rate is:

$$
q\left(t, t^{\prime}\right)=\frac{I(t)-R\left(t^{\prime}\right)}{R\left(t^{\prime}\right)}
$$

where $I(t)$ is the number of persons who immigrate to the United States in time period $t$ (where $t$ could be a single year, or an interval such as 1975-1980); and $R\left(t^{\prime}\right)$ is the number of those immigrants who remain in the United States as of $t^{\prime}\left(t^{\prime}>t\right)$. Throughout the analysis, we define $t^{\prime}$ to be the census date, April 1, 1980. To estimate the size of $I$ and $R$, we use two basic data sources: the microdata on Aliens Legally Admitted for Permanent Residence in the U.S., available from the Immigration and Naturalization Service, and the Public Use File of the 1980 U.S. Census. 
The INS microdata contain a record for every legal immigrant admitted into the country between July 1, 1971 and September 30, 1986. Each record contains limited information on the demographic characteristics of the immigrant, as well as the date of entry into the United States. It is important to stress that these data only contain observations on aliens legally admitted into permanent residence during that period. Therefore, the INS data do not include any persons who entered the United States illegally, or who entered by using a student visa, a business visa, or a visitor's visa, unless these persons eventually adjusted their status to permanent residence. If they did adjust their status, however, the INS includes them in the file, and reports both the date of their initial entry into the United States and the date in which the status change took place. Hence the INS microdata can be used to estimate the number of foreign-born persons who should have been present in the United States on April 1, 1980.12

To calculate the size of the legal immigrant flow, $I(t)$, we make one adjustment on the INS data. Because the INS reports each immigrant's age, sex, and country of birth, we use age and sex to construct mortality-adjusted immigrant counts for each of 70 source countries, and for each of the continents. ${ }^{13}$

The data on $R(t)$, the number of immigrants who remain in the United States, is drawn mainly from the 1980 Census. The Census enumerated all foreign-bom persons whose usual place of residence was in the United States as of April 1, 1980. This enumeration, however,

\footnotetext{
${ }^{12}$ Of course, because our INS data stops at the end of fiscal year 1986, it is possible that some persons who entered the country prior to 1980 do nol appear in the INS data at all because they changed status in 1987 or beyond. By 1986, hossever, il is unusual to find adjustments of status for persons who actually arrived in the country prior 101980 .

${ }^{13}$ In paricular, we use age/sex specific mortality rates to calculate the probability that an inmigrant is alive as of April 1, 1980.
} 
included many foreign-born persons who are absent from the INS counts, such as illegal aliens and "nonimmigrants" (e.g., foreign students and visitors to the United States for lengthier business stays) who did not eventually adjust their status to permanent residence. ${ }^{14}$

In order to make the Census count of immigrants who remained in the United States compatible with the official INS count of who should have been present in the country, we adjust the Census data for the presence of these groups. Warren and Passel (1987) report that the 1980 Census enumerated 2.1 million foreign-bom persons who were not legally admitted into the country. They also estimate the number of illegal aliens who originated in each of a large number of source countries, with about 1.1 million of the illegal aliens originating in Mexico.

We use the Warren-Passel counts to adjust the 1980 Census data. In particular, for each source country we subtract their estimates of the illegal population from the Census enumeration. This procedure has the potential problem that the Warren-Passel estimates are based on their own set of assumptions. Hence, our calculations may simply give us back some of the assumptions underlying the Warren-Passel analysis.

We do not believe, however, that this presents a serious problem for our study. Various data sources, including mortality statistics of the foreign-born residing in the United States and counts from the Mexican census, suggest that the number of illegal aliens in the United States is in the range suggested by the Warren-Passel estimates. is Moreover, an alternative (and independent) source of data on illegal immigration can be obtained from the size of the population

\footnotetext{
${ }^{14}$ The INS data also omits refugees who do not adjust status to permanent residence. This population, however, is very small compared to those of illegal aliens and non-immigrants. Our estimated outmigration rates do adjust the Census data for these uncounted refugees. For details, see Bratsberg (1991).

is The evidence is reviewed in Passel (1986) and Borjas, Freeman, and Lang (1990).
} 
that applied for amnesty under the provisions of the 1986 Immigration Reform and Control Act. About 1.8 million persons who entered illegally prior to 1982 , as well as an additional 1.3 million workers who worked in certain agricultural jobs during the mid-1980s, applied for amnesty. The Warren-Passel counts, therefore, are not far off the mark. To check the sensitivity of our estimates, we used the source-country distribution in the amnesty data, and applied it to the 2.1 million Warren-Passel illegal count so as to obtain a different series of illegal persons enumerated by the Census. The correlation between the two series was very high (over .97). Hence we use the simpler, and perhaps more reliable, Warren-Passel estimates throughout the paper.

A second problem with the Census data is that it contains a number of foreign-born students who are not legal immigrants (i.e., who have not adjusted status into permanent residence). Over 100,000 students entered the country annually during the 1970 s. Internal INS calculations--obtained from the I-53 forms that aliens residing in the United States were required to complete annually prior to 1980 --report that 170,000 foreign students were present in the country in 1980.16 We use the source country distribution of foreign students admitted in the United States during the 1970s to allocate these students to particular national origin groups, and then subtract out the estimated number of foreign students from the Census counts.

Finally, the Census data enumerated some persons who entered the United States for lengthy business stays. Although the flow of business entrants is substantial, it has received little attention in the literature. During the 1970 s, for instance, approximately 560,000 business visitors entered the United States per year (most of them for short-term visits). According to the INS, approximately 186,000 business aliens filled out the I- 53 forms in 1980 , and can be presumed to

\footnotetext{
${ }^{16}$ These counls were made available to us by Robert Warren.
} 
be residing in the United States for lengthier periods. ${ }^{17}$ Using the source-country distribution of business aliens in published INS statistics, we allocate these persons to the various source countries, and again subtract the resulting estimates from the Census population counts.

Using these adjustments, the 1980 Census allows us to estimate the number of legal immigrants who arrived prior to 1980 and who were present in the United States on April 1, 1980. We calculate this number for two cohorts: $1975-1980$ and $1970-1974$ arrivals. ${ }^{18}$ To estimate the emigration rate, we contrast these data with the counts provided by the INS data of who should have been present in the United States. Note, however, that for the earlier cohort, the INS counts only persons who arrived between July 1, 1971 and December 31, 1974. Hence we adjust the INS counts to make them a full five-year Census interval. ${ }^{19}$

The estimated outmigration rates are reported in Table 1, by continent and country of origin. The table also reports our estimate of the number of legal immigrants (after adjusting for mortality), and the Census count of these immigrants (after adjusting for the presence of illegal aliens and nonimmigrants). Of the 2 million legal immigrants who arrived in the U.S. between 1970 and 1974, approximately 1.6 million were enumerated in the 1980 Census, thus the earlier cohort has an outmigration rate of 21.5 percent. Of the 2.6 million immigrants who arrived between January 1, 1975 and April 1, 1980, about 2.1 million were enumerated by the 1980

\footnotetext{
17"These include "exchange aliens" and "all other aliens."

${ }^{18} \mathrm{We}$ allocate illegal aliens, students, and business migrants to the two cohorts based on the proportions reported in the original data sources.

${ }^{19}$ Our adjustment is actually a bit more complex. We use the actual number of immigrants admitted between 1970 and June 1, 1971 (as reported by the published INS statistics) to "blow up" the statistics for the earlier cohort.
} 
Census, leading to an outmigration rate of 17.5 percent. The data thus suggest that outmigration, if it occurs at all, typically occurs soon after immigration. ${ }^{20}$

Table $l$ also shows that the outmigration rate varies significantly across the various source countries. Typically, outmigration rates are lowest for immigrants originating in Asia. Only 3.5 percent of Asian immigrants who arrived in the United States after 1975 had left the country by 1980, as compared to 18.4 percent of European immigrants, 24.8 percent of South American immigrants, and 34.5 percent of North American immigrants. We note that for some immigrant groups (e.g., Japanese immigrants in the late 1970s), the estimated outmigration rate is negative. In other words, even after the various corrections, the Census enumerated many more Japanese immigrants than were legally admitted by the INS. This problem probably arises because our correction for the presence of Japanese business persons in the Census counts was not sufficiently large. It is worth noting that this problem tends to disappear in the analysis of the earlier (19701974) cohort, and that with the exception of Japan and Taiwan, most of the countries with negative outmigration rates are relatively unimportant sources of immigration. In the empirical analysis reported below, we set the negative outmigration rates to a value of .0001 .

We conclude this section by noting that our estimates are generally consistent with other studies addressing outmigration among immigrants. For example, Jasso and Rosenzweig (1982) estimate upper and lower bounds on outmigration as of January 1979 among immigrants who arrived in the United States during the fiscal year 1971. While Jasso and Rosenzweig's estimates in general are higher than ours, the across country distribution of outmigration rates is very

\footnotetext{
${ }^{20}$ This finding is consistent with that of Warren and Peck (1980), who estimate that 18.0 percent of recenty admitted (1960-1970) immigrants and 5.2 percent of the 1960 stock of immigrants left the United States between 1960 and 1970.
} 
consistent with that in Table 1. For the countries that overlap between the two studies, the simple correlation coefficient between Jasso and Rosenzweig's upper bound estimates and our figures for the 1970-74 cohort is .71 . This lends additional credence to our analysis below, where we exploit the variation in outmigration rates across countries to test some of the predictions of our model.

\section{Determinants of the Outmigration Rate}

Our estimates of the outmigration rate are obviously measured with substantial error. Nevertheless, we now show that the variation in these rates across national origin groups can be understood in terms of the basic economic characteristics that guide the outmigration decision.

Table 2 presents regressions of the outmigration rate on various source country characteristics, including the source country's log per-capita GNP; the country's distance from the United States; whether the country has a communist regime; whether the country has recently experienced a coup or a revolution; and a measure of inequality in the source country's income distribution (which we interpret as a proxy for the rate of return to skills in the source country). ${ }^{21}$ To minimize the measurement problem, these regressions are estimated on the set of national origin groups and cohorts that had at least 125 persons enumerated in the $5 / 100$ sample of the 1980 Census. The regression, therefore, only contains 119 observations (53 observations from the 1970-1974 cohort, and 66 observations from the 1975-1980 cohort). Table 2 presents both weighted and unweighted regressions (where the weight is given by the size of the immigrant flow

\footnotetext{
${ }^{2 J}$ The per-capita GNP data is reported in U.S. Arms Control and Disarmament Agency (1982); the distance variable is obtained from Fitzpatrick and Madlin (1986); the political variables are reported in Taylor and Jodice (1983); and the income inequality measure is computed from Jain (1975), Taylor and Jodice (1983), and the World Bank (various issues).
} 
in the out-migration equation), as well as regressions using both the linear probability model and a grouped probit specification. ${ }^{22}$

Regardless of which specification one considers, a key variable determining the outmigration rate is the per-capita GNP in the source country. Immigrants tend to return to rich countries, not to poor countries. This is precisely the implication of the theoretical model presented earlier. This effect is also numerically important: in the unweighted linear probability model regression, for example, a doubling of per-capita GNP increases the outmigration rate by 4.9 percentage points (using the specification in column 2). We use distance from the source country to the nearest major port in the United States as a proxy for migration costs. The regressions in Table 2 indicate that distance has a strong negative impact on the outmigration rate. Not surprisingly, an immigrant is more likely to return to a nearby country than to a distant one. Every 1000-mile increase in distance between the United States and the source country reduces the outmigration rate by 1.2 percentage points. ${ }^{23}$

The regression also includes a measure of income inequality in the source country (defined by the ratio of income accruing to the top 10 percent of the households to the income accruing to the bottom 20 percent of the households). It is interesting to note that these data are highly correlated with the rates of return to schooling estimated by Psacharapoulos (1973). ${ }^{24}$ The

\footnotetext{
${ }^{22}$ Although we prefer the weighted specifications (because the weights panially correct for the heteroscedasticity introduced by the fact that outmigration rates are likely to be measured with substantial error particularly for counlries with small immigrant flows), we report the unweighted regressions for comparison purposes.
}

${ }^{23}$ This and other resulis reported in Table 2 are robust 10 the exclusion of Mexico and Canada from the sample. For example, in the specification reported in column 2, the coefficient on distance is -.0150 and the t-statistic is -2.55 when Mexico and Canada are removed from the sample. In olher words, our results are nol driven by "border effects".

${ }^{24}$ Among the counlries common in our analysis and in the Psacharapoulos study, the correlation between the lwo measures is over 7 . 
theoretical model predicted that the relationship between the outmigration rate and the rate of return to skills should have an inverse-U shape with the peak occurring at the U.S. rate of return. The regressions reveal that the outmigration rate first increases and then decreases with the inequality measure (though this pattern is statistically insignificant in the unweighted regressions). The estimated coefficients suggest that the peak of this relationship occurs at a value of about 30 , even though the sample mean is only 9.0 , and the U.S. value of the inequality measure is 5.9 .

The additional variables in the regression characterize the source country's political structure, which are presumably an important component in the calculation of return migration costs. The presence of a communist regime in the source country has a strong negative impact on the outmigration rate. Holding other factors constant, the return migration rate of communist countries is about 18 percentage points lower than that of other countries.

Table 2 also presents analogous regressions using the in-migration rate--defined as the fraction of the source country's population that migrated to the United States--as a dependent variable. Although the two regressions are somewhat similar, they differ in one very striking way. In particular, the source country's per-capita GNP has a negative (though sometimes insignificant) impact on the in-migration rate, but a positive impact on the outmigration rate. This is precisely what one would expect if migration decisions are strongly affected by economic conditions in the source country (relative to those in the United States). The in-migration rate, like the outmigration rate, depends negatively on migration costs, as measured by distance. The impact of the political variables on the in-migration rate is harder to interpret, because local political 
conditions may prevent certain types of persons from leaving the country, and hence are not simply a reflection of the benefits and costs of immigration. 25

\section{Self-Selection and Outmigration}

The model presented in Section II predicts that return migration tends to accentuate the selection that originally characterized the immigrant flow. In other words, if the immigrant flow is positively selected, the outmigrants will be less skilled (on average) than the immigrants who remain in the United States. Alternatively, if the immigrant flow is negatively selected, the outmigrants will be more skilled than the immigrants who remain in the United States. Given the nature of Census-type data, it is not generally possible to conduct a direct test of this theoretical prediction because we have no direct measures on the skill composition of the return migration flow. Nevertheless, the Census data do allow an indirect test of the key theoretical insight.

The Public Use Sample of the 1980 Census reports earnings for persons residing in the United States as of the Census date. To determine the relative performance of immigrants in the U.S. labor market, we pool the samples of immigrants who arrived in the United States after 1970 and natives, and estimate the regression:

$$
\log w_{1}=X, \beta+\sum_{1} \delta_{j} C_{i j}+\theta_{i}
$$

\footnotetext{
${ }^{25}$ The regression also indicates that the in-migration rate is first an increasing and then a decreasing function of the income inequality variable. These results contradict the predictions of the model.
} 
where $w_{i}$ is the wage rate of individual $i ; X_{i}$ is a vector of socioeconomic characteristics fdefined below); and $C_{i j}$ is a dummy variable indicating if individual $i$ is an immigrant bom in country $j$. Equation (14) is estimated on the sample of working men aged 24-64 using the immigrant extract obtained from the S/100 A File of the 1980 Public Use Sample, and a 1/1000 random sample of natives.

The coefficient vector $\delta$ gives the immigrant wage (relative to that of natives) in the 1980 cross-section for the various national origin groups. We estimate these relative wages separately for each of the two immigrant cohorts under analysis (by interacting all variables in the regression with a cohort dummy). We also use two alternative specifications of the vector $X_{f}$. First, we calculate the wage differentials without controlling for differences in demographic characteristics (giving the unadjusted relative wage of immigrants). We also estimate the wage differentials after controlling for differences in education, age (and age squared), marital status, health, and metropolitan residence. The resulting wage differentials among national origin groups are reported in Table 3, and reveal the sizable variation that exists in U.S. labor market performance among immigrant groups and cohorts.

Consider the following regression model:

$$
\delta_{j}=\alpha_{0}+\alpha_{1} \tau_{j}+\alpha_{2} \tau_{j} p_{j}+\alpha_{3}\left(1-\tau_{j}\right) p_{j}+\alpha_{4} \tau_{j} q_{j}+\alpha_{5}\left(1-\tau_{j}\right) q_{j}+\omega_{j}
$$

where $\delta$, is the relative wage of national origin group $j ; \tau$, is a dummy variable set to unity if the source country has a higher rate of retum to skills than the United States; $p_{j}$ is the fraction of the source country's population that migrated to the United States; and $q_{j}$ is the fraction of the immigrant flow that returned to the country of origin. 
The specification in (15) captures the basic implications of our model of outmigration behavior. An increase in $p$, the fraction of the source country's population that migrated to the United States, should have a negative impact on immigrant earnings if the flow originates in a country with a lower rate of return to skills than the United States (i.e., $\alpha_{3}<0$ ). This occurs because the larger $p$, the more diluted the quality of the typical immigrant in a flow that is positively selected. By analogy, the coefficient $\alpha_{2}$ should be positive because the higher $p$, the greater the skills of the typical immigrant in a flow that is negatively selected.

The model also indicates that for given $\underline{p}$, a higher outmigration probability increases the intensity of the selection characterizing the group of immigrants who remain in the United States. Holding $p$ constant, therefore, an increase in $q$ increases the earnings of "stayers" if the immigrant flow originated in a country with a low rate of return to skills, and decreases the earnings of stayers if the flow originated in a country with a high rate of return to skills. This implies that $\alpha_{4}$ $<0$ and $\alpha_{s}>0$.

To proxy for the rates of return to skills in the source country, we use our constructed measure of income inequality in the source country. We define a dummy variable $\tau$ indicating if the source country has a higher rate of return to skills than the United States by comparing each country's value to the U.S. value (which is 5.91). ${ }^{26}$

As before, we restrict the regression analysis to immigrant flows that are well represented in the 1980 Census. Therefore, the regressions use only those national origin groups (and

\footnotetext{
${ }^{26}$ We also estimaled a model where the difference in income inequality between the source country and the United States is inieracied with the in-and out-migration probabilities (rather than the dummy indicating if this difference is positive or negative). Although the results tend to be similar, we report the simpler specification because of the large amount of measurement error implicil in the income inequality measures.
} 
horts) that have 125 or more observations in the $5 / 100$ Census file. We estimate equation (15) by pooling the two cohorts, giving us 119 observations that satisfy the sample size restriction.

Table 4 reports generalized least squares estimates for a number of alternative specifications of the regression model. ${ }^{27}$ In particular, the regression is estimated using both the unadjusted and adjusted relative wages of national origin groups. Because of potential endogeneity of the variables $p$ and $q$, the table also reports estimates based on two stage least squares. ${ }^{28}$ In addition, the regression specification is expanded to include the log per-capita GNP in the source country (relative to that in the U.S.), so as to control for the possibility that the skills obtained in industrialized economies are better valued by U.S. employers. This variable has been found to have a strong positive impact on immigrant earnings (Borjas, 1987), and it remains positive in the specifications reported in Table 4.

The empirical evidence indicates that an increase in the in-migration rate, $p$, from countries with low rates of return to skills lowers the average earnings of immigrants in the United States. The regressions, however, do not always indicate that an increase in migration from countries with high rates of return to skills increases the average earnings of immigrants. However, when this coefficient is negative, it is insignificant, and is much lower (in absolute value) than the respective coefficient for countries with low rates of return.

\footnotetext{
${ }^{27}$ Because the dependent variable is an estimated coefficient from a firsl-stage regression, the disturbance in the regression is heleroscedastic, with the variance of the error term depending on the standard ertor of the regression coefficient. To correcl for this problem, we used a generalized least squares estimator. For details, see Borjas (1987).

${ }^{28} \mathrm{The}$ instruments are predicted values from reduced form regressions on per-capita GNP, $\tau$, distance from the United Stales, whether the source country has a centrally planned economy, whether the source country experienced irregular executive transfers (i.e., a non-constitutional transfer of power in the executive branch), a dummy variable for the cohor, and dummies for the continent of origin.
} 
Table 4 shows that the impact of the outmigration rate on the earnings of immigrants who remain in the United States is precisely as suggested by theory. An increase in the outmigration rate increases average earnings if the immigrant flow is positively selected (i.e., originates in countries with low rates of return to skills) and decreases average earnings if the flow is negatively selected (i.e., originated in countries with high rates of return to skills). Outmigration behavior, therefore, accentuates the selection that characterized the immigrant flow.

As final evidence of the predictive power of our approach, we summarize evidence reported in Ramos' (1992) study of Puerto Rican return migration. By exploiting the information in both the 1980 U.S. Census and the Puerto Rican Census, Ramos can compare the education levels of three groups of persons: Puerto Ricans (i.e., persons born in Puerto Rico) who never migrated to the United States; Puerto Ricans who migrated to the U.S., but eventually returned to Puerto Rico; and Puerto Ricans who migrated to the U.S. permanently. The Census data indicate that Puerto Ricans who remained in Puerto Rico have an average education level of 10.8 years; Puerto Ricans who moved permanently to the U.S. have 9.5 years of schooling; and Puerto Ricans who moved to the U.S. but returned to Puerto Rico have 10.1 years of schooling. This is precisely the pattern in conditional means predicted by our model as long as Puerto Rico has a higher rate of return to skills than the United States. In fact, the rate of return to education in Puerto Rico is about 1.5 times the rate of return to education in the United States. It is not surprising, therefore, to observe the least skilled Puerto Ricans migrating to the United States, and to observe the most skilled among these workers eventually returning to their birthplace.

VI. Summary 
This paper presented a theoretical and empirical analysis of return migration behavior. Our theoretical model of return migration generates surprisingly strong predictions regarding the size and skill composition of the population flows. Perhaps the most striking implication is that retum migration intensifies the type of selection that generated the immigrant flow in the first place. In other words, if the immigrant flow is positively selected, so that immigrants have aboveaverage skills, the return migrants will be the least skilled immigrants. In contrast, if the immigrant flow is negatively selected, the retum migrants will be the most skilled immigrants.

A second contribution of our analysis is the construction of a series of outmigration rates for 70 source countries. We constructed these statistics by combining two data sources: the 1980 U.S. Census, and a recently available microdata set constructed by the Immigration and Naturalization Service which reports a number of demographic characteristics for every legal immigrant admitted into the United States since 1972. Our estimated outmigration rates exhibit substantial variation across national origin groups, and indicate that immigrants tend to return to countries that are not distant and that are not poor.

Finally, our empirical analysis confirms the theoretical prediction that the skill composition of the retum migrant flow depends on the type of selection that generated the immigrant flow in the first place. Because of the selective nature of return migration, the skill composition of the immigrant pool left behind in the United States is substantially different from than of the original immigrant flow. This finding has significant implications for studies of the economic impact of immigration and for immigration policy. In view of the growing importance of immigration as a component of demographic change in the United States, it is clear that the economic and social impacts of nonrandom return migration flows will need to be explored intensively in future research. 


\section{APPENDIX}

In the general formulation of our model, return migration may arise both because a temporary stay in the United States enhances earnings in the source country, and because a component of U.S. earnings cannot be observed from abroad. To understand the implications of the decision rules in equations (7)-(9), it is instructive to consider Figures A-1 and A-2. Figure A-l illustrates the various migration choices when $\eta<1$, and Figure A-2 illustrates the outcomes when $\eta>1$.

As implied by equation ( 8 ), the initial immigration decision is entirely determined by a truncation of the random variable $v$. In particular, if $\eta<1$, the migrant flow is positively selected, while if $\eta>1$, the migrant flow is negatively selected. The introduction of uncertainty in U.S. economic opportunities does not alter the type of selection that characterizes the immigrant flow because individuals migrate in order to maximize the expected value of income.

After arrival in the United States, the immigrant makes a random draw from the $g(\varepsilon)$ density, and reconsiders the profitability of his original decision. Obviously, the decision of whether to return to the source country depends on whether the draw is favorable or unfavorable. As Figures A-1 and A-2 indicate, only those persons who have relatively unfavorable draws become return migrants (regardless of whether there is positive or negative selection). Some workers who expected to migrate temporarily to the United States now will settle permanently because they receive particularly favorably draws. Others who expected the move to be permanent will return to the source country because of unfavorable draws. 
As long as $\rho(\nu, \varepsilon)=0$, it is easy to show that the skill composition of the return migration flow in this model is identical to the sorting implied by the human capital model presented above. In particular:

$$
\begin{aligned}
& E(v \mid \text { Migrate and Stay })>E(v \mid \text { Migrate and Return }), \quad \text { for } \eta<1, \\
& E(v \mid \text { Migrate and Stay })<E(v \mid \text { Migrate and Retur }), \quad \text { for } \eta>1 .
\end{aligned}
$$

If $\eta<1$, return migrants are relatively unskilled workers (selected from a skilled immigrant flow), while if $\eta>1$, return migrants are relatively skilled workers (selected from an unskilled immigrant flow). As before, return migration accentuates the selection that characterizes the original immigration. These results are trivially implied by Figures $A-1$ and $A-2$ because the random variable $v$ for return migrants is truncated from above when $\eta<1$, and from below when $\eta>1$. Although these insights exactly parallel those obtained earlier, they do not completely describe the economic experiences of immigrants and return migrants in the United States. In particular, U.S. earnings now depend not only on skills, but also on the particular draw from the density $g(\varepsilon)$. Because only those immigrants who have relatively low values of $\varepsilon$ return to their home countries, the comparison of actual earnings (determined by the sum $v+\varepsilon$ ) between those who stay and those who go back may lead to different results.

If $\eta<1$, it is easy to show that:

$$
\mathrm{E}(v+\varepsilon \mid \text { Migrate and Stay })>\mathrm{E}(v+\varepsilon \mid \text { Migrate and Return })
$$


As before, the actual earnings of return migrants are lower than the actual earnings of immigrants who remain in the United States. This follows from equation (A-1) because the return migrants are less skilled than the "stayers," and the conditional expectation of $v$ is higher for stayers than for the return migrants

This implication, however, cannot be derived when $\eta>1$ unless more structure is imposed on the joint density $h(v, \varepsilon)$. The problem is that the immigrants who stay in the United States have the lowest $\nu^{\prime}$ 's and the highest $\varepsilon^{\prime}$ s. One possible restriction on $h(\nu, \varepsilon)$ is that the random variable $\nu$ has a sufficiently larger variance than the random variable $\varepsilon$. It can then be shown that the earnings of those who stay in the United States are lower than the earnings of those who return home 


\section{REFERENCES}

Borjas, George J., "Assimilation, Changes in Cohort Quality, and the Earnings of Immigrants," Journal of Labor Economics 3 (October 1985), 463-489.

, "Self-Selection and the Earnings of Immigrants," American Economic Review 77 (September 1987), 531-553.

, "Immigrant and Emigrant Earnings: A Longitudinal Study," Economic Inquiry 27 (January 1989), 21-37.

Borjas, George J., Richard B. Freeman, and Kevin Lang, "Undocumented Mexican-Born Workers in the U.S.: How Many, How Permanent?" in John M. Abowd and Richard B. Freeman (eds.), Immigration, Trade, and the Labor Market (Chicago: University of Chicago Press, 1991).

Bratsberg, Bernt, Return Migration and Self-Selection: The Exodus of Foreign-Born from the United States, Unpublished Ph.D. Dissertation, University of Califomia, Santa Barbara, 1991.

DaVanzo, Julie, "Repeat Migration in the United States: Who Moves Back and Who Moves On?" Review of Economics and Statistics 65 (November 1983), 552-559.

Fields, Gary S., "Place to Place Migration: Some New Evidence," Review of Economics and Statistics 61 (February 1979), 21-32.

Fitzpatrick, Gary L. and Marilyn J. Madlin, Direct Line Distances, U.S. Edition (London: The Scarecrow Press, Inc., 1986).

Heckman, James J. and Bo E. Honoré, "The Empirical Content of the Roy Model," Econometrica 58 (September 1990), 1121-1150.

Jain, Shail, Size Distribution of Income (Washington, D.C.: World Bank, 1975).

Jasso, Guillermina and Mark R. Rosenzweig, "Estimating the Emigration Rates of Legal Immigrants Using Administrative and Survey Data: The 1971 Cohort of Immigrants to the United States," Demography 19 (August 1982), 279-290.

, "How well do U.S. immigrants do? Vintage Effects, Emigration Selectivity, and Occupational Mobility," Research in Human Capital and Development 6 (1988), 229 253.

Lam, Kit-Chun, An analysis of the Outmigration of Foreign-Born Members in a Population, Unpublished Ph.D. Dissertation, Harvard University, 1987. 
Passel, Jeffrey, "Undocumented Immigration," The Annals of the American Academy of Political and Social Science 487 (September 1986), 181-200.

Pessino, Carola, "Sequential Migration Theory and Evidence from Peru," Journal of Development Economics 36 (July 1991), 55-87.

Psacharopoulos, George, Returns to Education: An International Comparison (San Francisco: Jossey-Bass, 1973).

Ramos, Fernando, "Out-Migration and Return Migration of Puerto Ricans," in George J. Borjas and Richard B. Freeman (eds.), Immigration and the Work Force: Economic Consequences for the United States and Source Areas (Chicago: University of Chicago Press, 1992).

Rosen, Sherwin, "Learning and Experience in the Labor Market," Journal of Human Resources 7 (Summer 1972), 326-342.

Roy, Andrew D., "Some Thoughts on the Distribution of Earnings," Oxford Economic Papers 3 (June 1951), 135-146.

Taylor, Charles Lewis and David A. Jodice, World Handbook of Political and Social Indicators, Third Edition (New Haven, Conn.: Yale University Press, 1983).

Tunali, Insan, "A General Structure for Models of Double-Selection and an Application to a Joint Migration/Earnings Process with Remigration," Research in Labor Economics 8 (1986, Part B), 235-282.

U.S. Arms Control and Disarmament Agency, World Military Expenditures and Arms Transfers (Washington, D.C.: Government Printing Office, 1982).

U.S. Immigration and Naturalization Service, Statistical Yearbook (Washington, D.C.: Government Printing Office, various issues).

Warten, Robert and Ellen Percy Kraly, "The Elusive Exodus: Emigration from the United States," Population Trends and Public Policy (March 1985, no.7).

Warren, Robert and Jeffrey Passel, "A Count of the Uncountable: Estimates of Undocumented Aliens Counted in the 1980 Census," Demography 24 (August 1987), 375-393.

Warten, Robert and Jennifer Marks Peck, "Foreign-Born Emigration from the United States: 1960-1970," Demography 17 (February 1980), 71-84.

World Bank, World Development Report (New York: Oxford University Press, various issues). 
ABLE 1: ESTIMATED OUTMIGRATION RATES

1975-80 Cohort $\quad 1970.74$ Gohort

$\begin{array}{ccccc}\text { INS Count } & \text { Census } & \text { Out- } & \text { INS Count } & \text { Census } \\ \text { of Legal } & \text { Count of Migration of Legal } & \text { Count of Migration } \\ \text { Immigrants } & \text { Immigrants } & \text { Rate Immigrants Immigrants Rate }\end{array}$

\begin{tabular}{|c|c|c|c|c|c|c|}
\hline TOTAL & 2591680 & 2136994 & 0.175 & 1985274 & 1557477 & 0.215 \\
\hline EUROPE & 416490 & 339652 & 0.184 & 451324 & 343774 & 0.238 \\
\hline AUSTRIA & 2014 & 2484 & -0.234 & 2380 & 2427 & -0.020 \\
\hline BELGIUM & 1985 & 1145 & 0.423 & 1941 & 1207 & 0.378 \\
\hline CHECKOSLOVAKIA & 3824 & 3433 & 0.102 & 6170 & 5016 & 0.187 \\
\hline DENMARK & 2145 & 1592 & 0.258 & 2303 & 1355 & 0.412 \\
\hline FINLAND & 1524 & 1853 & -0.216 & 1722 & 1224 & 0.289 \\
\hline FRANCE & 8380 & 1684 & 0.799 & 9085 & 5920 & 0.348 \\
\hline GERMANY & 34586 & 28455 & 0.177 & 37406 & 34109 & 0.088 \\
\hline GREECE & 35686 & 22536 & 0.368 & 60867 & 39046 & 0.359 \\
\hline HUNCARY & 4448 & 4487 & -0.009 & 6989 & 6609 & 0.054 \\
\hline IRELAND & 5446 & 4407 & 0.191 & 8417 & 5301 & 0.370 \\
\hline ITALY & 37006 & 25996 & 0.298 & 95692 & 69840 & 0.270 \\
\hline NETHERLANDS & 5333 & 1793 & 0.664 & 5480 & 3712 & 0.323 \\
\hline NORWAY & 1825 & 1137 & 0.377 & 2022 & 1015 & 0.498 \\
\hline POLAND & 22651 & 22426 & 0.010 & 22108 & 21930 & 0.008 \\
\hline PORTUGAL & 49293 & 41622 & 0.156 & 55174 & 51125 & 0.073 \\
\hline ROMANIA & 11773 & 11605 & 0.014 & 7407 & 7106 & 0.041 \\
\hline SPAIN & 9515 & 6637 & 0.302 & 15731 & 14571 & 0.074 \\
\hline SWEDEN & 3168 & 2153 & 0.320 & 3017 & 1532 & 0.492 \\
\hline SWITZERLAND & 3210 & 2243 & 0.301 & 3355 & 1857 & 0.447 \\
\hline USSR & 89542 & 89306 & 0.003 & 10491 & 10388 & 0.010 \\
\hline UNITED KINGDOM & 68008 & 46202 & 0.321 & 55339 & 38086 & 0.312 \\
\hline YUGOSLAVIA & 12631 & 9091 & 0.280 & 31191 & 23037 & 0.261 \\
\hline ASIA & 1124026 & 1085239 & 0.035 & 587844 & 519994 & 0.115 \\
\hline BANGLADESH & 2915 & 3146 & -0.079 & 1092 & 1825 & -0.671 \\
\hline CHINA & 81308 & 80960 & 0.004 & 60777 & 57964 & 0.046 \\
\hline HONG KONG & 26713 & 24506 & 0.083 & 21774 & 20493 & 0.059 \\
\hline INDIA & 92900 & 91654 & 0.013 & 68658 & 64224 & 0.065 \\
\hline INDONESIA & 3952 & 5702 & -0.443 & 2747 & 2733 & 0.005 \\
\hline IRAN & 62430 & 35921 & 0.425 & 13780 & 8092 & 0.413 \\
\hline IRAQ & 16181 & 14840 & 0.083 & 7741 & 6937 & 0.104 \\
\hline ISRAEL & 15411 & 12777 & 0.171 & 10942 & 8951 & 0.182 \\
\hline JAPAN & 19858 & 33017 & -0.663 & 25713 & 19322 & 0.249 \\
\hline KOREA & 157294 & 157816 & -0.003 & 98723 & 96585 & 0.022 \\
\hline LEBANON & 24691 & 24120 & 0.023 & 10524 & 8938 & 0.151 \\
\hline MALAYSIA & 3215 & 5722 & -0.780 & 1610 & 1719 & -0.068 \\
\hline PAKISTAN & 17615 & 15179 & 0.138 & 12601 & 9632 & 0.236 \\
\hline PHILIPPINES & 197092 & 181262 & 0.080 & 146422 & 152430 & -0.041 \\
\hline SINGAPORE & 1567 & 2356 & -0.503 & $\begin{array}{r}14022 \\
827\end{array}$ & 800 & 0.032 \\
\hline SRI LANKA & 2017 & 2727 & -0.352 & 1969 & 1303 & 0.338 \\
\hline TAIWAN & 34006 & 36892 & -0.085 & 18412 & 17543 & 0.047 \\
\hline THAILAND & 23903 & 23018 & 0.037 & 21360 & 19329 & 0.095 \\
\hline TURXEY & 9623 & 10614 & -0.103 & 8974 & 7380 & 0.178 \\
\hline
\end{tabular}


TABLE 1 (CONTINUED)

1975-80 Cohort

1970-74 Cohort

\begin{tabular}{|c|c|c|c|c|c|c|}
\hline & $\begin{array}{r}\text { INS Count } \\
\text { of Legal } \\
\text { Immigrants }\end{array}$ & $\begin{array}{c}\text { Census } \\
\text { Count of } \\
\text { Immigrants }\end{array}$ & $\begin{array}{c}\text { Out- } \\
\text { Migration } \\
\text { Rate }\end{array}$ & $\begin{array}{l}\text { INS Count } \\
\text { of Legal } \\
\text { Immigranes }\end{array}$ & $\begin{array}{c}\text { Census } \\
\text { Count of } \\
\text { Immtgrants }\end{array}$ & $\begin{array}{l}\text { Out- } \\
\text { Migratior } \\
\text { Rate }\end{array}$ \\
\hline AFRICA & $\begin{array}{l}59710 \\
13748\end{array}$ & $\begin{array}{r}43962 \\
7607\end{array}$ & $\begin{array}{l}0.264 \\
0.447\end{array}$ & $\begin{array}{l}39122 \\
13180\end{array}$ & $\begin{array}{r}23747 \\
6958\end{array}$ & $\begin{array}{l}0.393 \\
0.472\end{array}$ \\
\hline KENYA & 2792 & 2240 & 0.198 & 1951 & 1258 & 0.355 \\
\hline MOROCCO & 2234 & 1270 & 0.432 & 2208 & 1197 & 0.458 \\
\hline SIERRA LEONE & 863 & 407 & 0.528 & 1104 & 794 & 0.281 \\
\hline SOUTH AFRICA & 8721 & 4397 & 0.496 & 2579 & 1055 & 0.591 \\
\hline TANZANIA & 1503 & 1021 & 0.321 & 1527 & 856 & 0.440 \\
\hline UGANDA & 1296 & 1024 & 0.210 & 2541 & 1401 & 0.449 \\
\hline ZAMBIA & 1072 & 613 & 0.428 & 329 & 114 & 0.653 \\
\hline NORTH AMERICA & 797604 & 522468 & 0.345 & 773743 & 572834 & 0.260 \\
\hline CANADA & 66795 & 59465 & 0.110 & 51628 & 40421 & 0.217 \\
\hline CosTA RICA & 7728 & 3615 & 0.532 & 5428 & 4806 & 0.115 \\
\hline CUBA & 42531 & 40929 & 0.038 & 136654 & 136342 & 0.002 \\
\hline DOMINICAN REP. & 80984 & $\$ 5922$ & 0.309 & 66829 & 49178 & 0.264 \\
\hline EL SALVADOR & 22541 & 18727 & 0.169 & 10693 & 10613 & 0.008 \\
\hline GUATEMALA & 15994 & 12403 & 0.225 & 9835 & 9244 & 0.060 \\
\hline HAITI & 31598 & 15288 & 0.516 & 30425 & 13107 & 0.569 \\
\hline HONDURAS & 10346 & 5945 & 0.425 & 7906 & 6147 & 0.222 \\
\hline JAMAICA & 80102 & 56725 & 0.292 & 66380 & 39676 & 0.402 \\
\hline MEXICO & 328215 & 192141 & 0.415 & 309895 & 229611 & 0.259 \\
\hline PANAMA & 14189 & 8486 & 0.402 & 8372 & 6027 & 0.280 \\
\hline TRIN. \& TOBAGO & 28692 & 13993 & 0.512 & 35011 & 17619 & 0.497 \\
\hline SOUTH AMERICA & 173468 & 130497 & 0.248 & 118628 & 88857 & 0.251 \\
\hline ARGENT INA & 14827 & 11810 & 0.203 & 11878 & 10011 & 0.157 \\
\hline BRAZIL & 7929 & 5722 & 0.278 & 6693 & 3372 & 0.496 \\
\hline CHILE & 12486 & 8234 & 0.341 & 6563 & 6063 & 0.076 \\
\hline COLOMBIA & 46136 & 34745 & 0.247 & 34051 & 28254 & 0.170 \\
\hline ECUADOR & 26132 & 20874 & 0.201 & 24436 & 21208 & 0.132 \\
\hline PERU & 20644 & 14284 & 0.308 & 10593 & 9289 & 0.123 \\
\hline URUGUAY & 4747 & 3413 & 0.281 & 3482 & 2647 & 0.240 \\
\hline OCEANIA & 20382 & 15176 & 0.255 & 14613 & 8272 & 0.434 \\
\hline AUSTRALIA & 7241 & 3229 & 0.554 & 6810 & 3944 & 0.421 \\
\hline NEW ZEALAND & 3000 & 1852 & 0.383 & 2321 & 802 & 0.655 \\
\hline
\end{tabular}


$\operatorname{TABLE} 2^{*}$

DETERMINANTS OF OUTMIGRATION AND IN-MIGRATION RATES

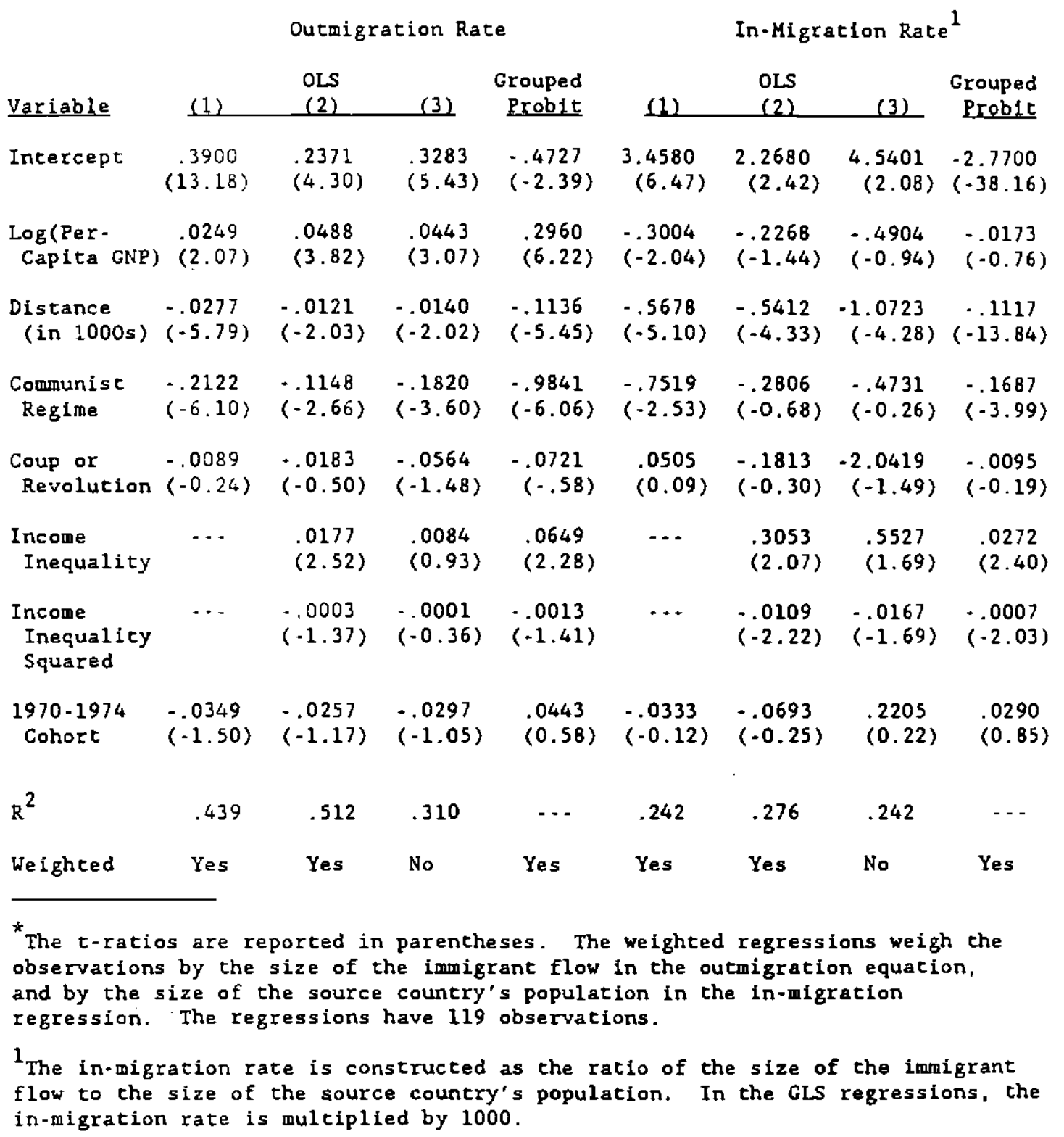


TABLE 3

Log Wage of Immigrants in 1980, By Cohort and National Origin Group (Relative to Natives)

1975-80 Cohort

Unadjusted Adjusted
Wage

EUROPE :

\begin{tabular}{|c|c|c|}
\hline & & \\
\hline AUS TR IA & -0.027 & -0.058 \\
\hline BELGIUM & $0.414 *$ & $0.274 *$ \\
\hline CHECKOSLOVAKIA & 0.051 & -0.067 \\
\hline DENMARK & $0.414 *$ & $0.387 *$ \\
\hline FINLAND & 0.183 & 0.135 \\
\hline FRANCE & $0.219 *$ & $0.152 *$ \\
\hline GERMANY & $0.275 *$ & $0.182 \star$ \\
\hline GREECE & $-0.330 *$ & $-0.220 *$ \\
\hline HUNGARY & $-0.167 *$ & $-0.167 *$ \\
\hline IRELAND & $-0.188 *$ & $-0.186 *$ \\
\hline ITALY & $-0.119 *$ & -0.057 \\
\hline NETHERLANDS & $0.329 *$ & $0.218 *$ \\
\hline NORWAY & $0.239 \star$ & $0.203 *$ \\
\hline POLAND & $-0.346 *$ & $-0.343 *$ \\
\hline PORTUGAL & $-0.296 *$ & -0.046 \\
\hline ROMANIA & $-0.249 *$ & $-0.299 *$ \\
\hline SPAIN & $-0.184 *$ & $-0.199 *$ \\
\hline SWEDEN & $0.189 *$ & 0.097 \\
\hline SWITZERLAND & $0.245 *$ & $0.203 *$ \\
\hline USSR & $-0.245 *$ & $-0.360 *$ \\
\hline UNITED KINGDOM & $0.204 *$ & $0.111 *$ \\
\hline YUGOSLAVIA & $-0.125 *$ & -0.039 \\
\hline STA: & & \\
\hline BANGLADESH & $-0.206 *$ & $-0.275 *$ \\
\hline CHINA & $-0.491 *$ & $-0.469 *$ \\
\hline HONG KONC & $-0.371 *$ & $-0.325 *$ \\
\hline INDIA & $-0.176 *$ & $-0.288 *$ \\
\hline INDONESIA & $-0.163 *$ & $-0.265 *$ \\
\hline IRAN & $-0.192 *$ & $-0.216 *$ \\
\hline IRAQ & $-0.296 *$ & $-0.242 *$ \\
\hline ISRAEL & $-0.197 *$ & $-0,224 *$ \\
\hline JAPAN & $0.175 *$ & $0.068 *$ \\
\hline KOREA & $-0.291 \star$ & $-0.369 *$ \\
\hline LEBANON & $-0.191 *$ & $-0.130 *$ \\
\hline MALAYSIA & $-0.350 *$ & $-0.347 *$ \\
\hline PAKISTAN & $-0.283 *$ & $-0.314 \star$ \\
\hline PHILIPPINES & $-0.339 \star$ & $-0.373 *$ \\
\hline SINGAPORE & 0.052 & -0.012 \\
\hline SRI LANKA & -0.010 & -0.146 \\
\hline TAIWAN & $-0.295 *$ & $-0.328 *$ \\
\hline THAILAND & $-0.464 x$ & $-0.450 \star$ \\
\hline TURKEY & $-0.195 \star$ & $-0.182 *$ \\
\hline
\end{tabular}

1970-74 Cohort

\begin{tabular}{cc}
$\begin{array}{c}\text { Unadjusted } \\
\text { Wage }\end{array}$ & $\begin{array}{c}\text { Adjusted } \\
\text { Wage }\end{array}$ \\
\hline
\end{tabular}

$\begin{array}{cc}0.193 & 0.115 \\ 0.154 & 0.001 \\ -0.009 & -0.102 \\ 0.048 & 0.032 \\ 0.141 & 0.175 \\ 0.143 * & 0.086 \\ 0.226 * & 0.152 \star \\ -0.322 \star & -0.237 * \\ -0.086 & -0.129 * \\ -0.049 & -0.038 \\ -0.121 * & -0.000 \\ -0.097 & -0.189 \star \\ 0.425 * & 0.278 \\ -0.039 & -0.045 \\ -0.210 * & -0.011 \\ 0.136 * & -0.024 \\ -0.058 & -0.029 \\ 0.218 & 0.163 \\ 0.211 & 0.161 \\ 0.003 & -0.035 \\ 0.218 * & 0.111 * \\ -0.031 & 0.011\end{array}$

0.065

.0 .094

$-0.309 *$

$-0.364 *$

$-0.215 *$

$-0.192 *$

$0.204 * \quad-0.040 *$

$-0.062$

$-0.150$

$-0.018$

$-0.094 *$

$-0.060$

$-0.099 *$

0.072

0.010

$-0.122 *$

$-0.045$

0.028

$-0.050 *$

$0.420 *$

0.183

0.066

$-0.191 *$

0.013

$-0.085$

$-0.109 *$

0.004

$-0.171 *$

$-0.144 \star$

$-0.106$

$-0.094 *$

$-0.169 \star$

0.229

$-0.050$

$-0.134 *$

$-0.232 \star$

0.016 
TABLE 3 (CONTINUED)

1975-80 Cohort

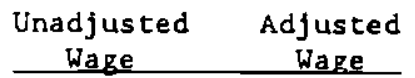

AFRICA:

$\begin{array}{rcc}\text { EGYPT } & -0.253 * & -0.348 \star \\ \text { KENYA } & -0.161 & -0.241 \star \\ \text { MOROCCO } & -0.147 & -0.164 \\ \text { SIERRA LEONE } & -0.023 & 0.006 \\ \text { SOUTH AFRICA } & 0.255 * & 0.058 \\ \text { TANZANIA } & -0.181 & -0.264 \star \\ \text { UGANDA } & -0.317 \star & -0.461 \star \\ \text { ZAMBIA } & 0.676 \star & 0.720 \star\end{array}$

NORTH AMERICA:

CANADA

COSTA RICA CUBA

DOMINICAN REP.

EL SALVADOR GUATEMALA

HAITI

HONDURAS

JAMAICA

MEXICO

PANAMA

TRIN. \& TOBACO

SOUTH AMERICA:

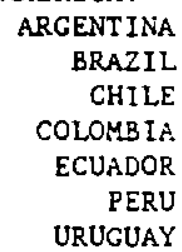

$$
\begin{aligned}
& 0.187 \star \\
& -0.437 \star \\
& -0.496 \star \\
& -0.643 \star \\
& -0.606 \star \\
& -0.568 \star \\
& -0.599 \star \\
& -0.474 \star \\
& -0.331 \star \\
& -0.623 \star \\
& -0.384 \star \\
& -0.372 \star
\end{aligned}
$$

$0.130 *$ $-0.307 *$ $-0.488 \star$ $-0.446 *$ $-0.358 *$ $-0.353 *$ $-0.467 *$ $-0.326 *$

$-0.275 *$

$-0.299 *$

$-0.342 \star$

-0.292 *
$-0.075$

0.061

$.0 .230 *$

$-0.111 *$

0.021

-0.401 *

$-0.258 *$

$-0.328 *$

-0.486 *

$-0.400 \star$

$-0.377 *$

$-0.372 *$

$-0.411 *$

$-0.365 *$

$\begin{array}{lc}0.115 \star & -0.104 \star \\ 0.144 & 0.019 \\ 0.015 & -0.069 \\ -0.222 & -0.315 \star \\ 0.293 \star & 0.097 \\ 0.064 & -0.072 \\ -0.021 & -0.053 \\ 0.030 & 0.069\end{array}$

1970-74 Cohort

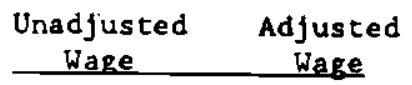

Wage Wage
$0.144 *$
$-0.001$
0.060
$-0.052$
$0.302 \star$
0.130
$0.176 \star$ 0.090

*The coefficient is significant in a two-tail test at the 5 percent level of significance. 
TABLE $4^{*}$

Relationship Between Conditional Wage of Immigrants in the United States and Outmigration Rates

\begin{tabular}{|c|c|c|c|c|c|c|}
\hline \multirow[b]{3}{*}{ Variable } & \multicolumn{3}{|c|}{ Unadjusted Wage } & \multicolumn{3}{|c|}{ Adfusted Wage } \\
\hline & \multicolumn{2}{|c|}{ GLS } & \multirow[b]{2}{*}{$\underline{2 S L S}$} & \multicolumn{2}{|c|}{ GLS } & \multirow[b]{2}{*}{$\underline{2 S L S}$} \\
\hline & (1) & $(2)$ & & $(1)$ & $(2)$ & \\
\hline Intercept & $\begin{array}{l}-.1494 \\
(-3.62)\end{array}$ & $\begin{array}{l}-.0210 \\
(-.42)\end{array}$ & $\begin{array}{r}-.0597 \\
(-.83)\end{array}$ & $\begin{array}{l}-.2232 \\
(-7.19)\end{array}$ & $\begin{array}{l}-.0608 \\
(-1.87)\end{array}$ & $\begin{array}{l}-.1160 \\
(-2.51)\end{array}$ \\
\hline$r$ & $\begin{array}{l}-.1289 \\
(-2.11)\end{array}$ & $\begin{array}{l}-.1104 \\
(-1.92)\end{array}$ & $\begin{array}{l}.0009 \\
(.01)\end{array}$ & $\begin{array}{r}-.0064 \\
(-.14)\end{array}$ & $\begin{array}{l}.0178 \\
(.48)\end{array}$ & $\begin{array}{l}.0773 \\
(1.05)\end{array}$ \\
\hline$r * p$ & $\begin{array}{r}-.0022 \\
(-.68)\end{array}$ & $\begin{array}{r}-.0021 \\
(-.70)\end{array}$ & $\begin{array}{l}. .0101 \\
(-.35)\end{array}$ & $\begin{array}{c}-.0011 \\
(\cdot .47)\end{array}$ & $\begin{array}{r}-.0010 \\
(-.55)\end{array}$ & $\begin{array}{l}.0449 \\
(2.45)\end{array}$ \\
\hline$(1-r) * p$ & $\begin{array}{l}-.0264 \\
(-3.16)\end{array}$ & $\begin{array}{l}-.0278 \\
(-3.55)\end{array}$ & $\begin{array}{l}-.1462 \\
(-2.28)\end{array}$ & $\begin{array}{l}-.0167 \\
(-2.65)\end{array}$ & $\begin{array}{l}-.0185 \\
(-3.66)\end{array}$ & $\begin{array}{l}-.0975 \\
(-2.37)\end{array}$ \\
\hline$r * q$ & $\begin{array}{l}-.2482 \\
(-1.43)\end{array}$ & $\begin{array}{l}-.3180 \\
(-1.95)\end{array}$ & $\begin{array}{l}-.4056 \\
(-1.10)\end{array}$ & $\begin{array}{l}-.0826 \\
(-.63)\end{array}$ & $\begin{array}{l}-.1675 \\
(-1.58)\end{array}$ & $\begin{array}{l}-.5462 \\
(-2.30)\end{array}$ \\
\hline$(1-7) * q$ & $\begin{array}{l}.4698 \\
(3.27)\end{array}$ & $\begin{array}{l}.2972 \\
(2.10)\end{array}$ & $\begin{array}{l}1.0220 \\
(3.76)\end{array}$ & $\begin{array}{l}.5234 \\
(4.85)\end{array}$ & $\begin{array}{l}.3053 \\
(3.35)\end{array}$ & $\begin{array}{r}1.0559 \\
(6.09)\end{array}$ \\
\hline $\begin{array}{c}1970.1974 \\
\text { Cohort }\end{array}$ & $\begin{array}{l}.1223 \\
(3.36)\end{array}$ & $\begin{array}{l}.1269 \\
(3.70)\end{array}$ & $\begin{array}{l}.1126 \\
(3.11)\end{array}$ & $\begin{array}{l}.0977 \\
(3.55)\end{array}$ & $\begin{array}{l}.1038 \\
(4.69)\end{array}$ & $\begin{array}{l}.0820 \\
(3.52)\end{array}$ \\
\hline \multirow[t]{2}{*}{$\begin{array}{l}\log (\operatorname{Per}- \\
\text { Capita GNP) }\end{array}$} & $\cdots$ & $\begin{array}{l}.0646 \\
(4.00)\end{array}$ & $\begin{array}{l}.0704 \\
(3.76)\end{array}$ & $\cdots$ & $\begin{array}{l}.0820 \\
(7.87)\end{array}$ & $\begin{array}{l}.0872 \\
(7.27)\end{array}$ \\
\hline & .401 & .476 & .502 & .325 & .567 & .592 \\
\hline $\begin{array}{l}\text { The t-ratios } \\
\text { unity if the } \\
\text { p gives the fr } \\
\text { United states; } \\
\text { the source cou } \\
\text { to correct for } \\
\text { regressions ha }\end{array}$ & $\begin{array}{l}\text { are repo } \\
\text { source co } \\
\text { raction o } \\
\text { and } q \mathrm{~g} \\
\text { intry. I } \\
\text { the het } \\
\text { ave } 119 \text { o }\end{array}$ & $\begin{array}{l}\text { ed in par } \\
\text { try has II } \\
\text { the sourc } \\
\text { es the fr } \\
\text { regressi } \\
\text { oscedast } 1\end{array}$ & $\begin{array}{l}\text { ieses. } \\
\text { Income } \\
\text { Duntry's } \\
\text { ion of tl } \\
\text { use a g } \\
y \text { in the }\end{array}$ & $\begin{array}{l}\text { umy var } \\
\text { ilty th } \\
\text { ation t } \\
\text { igrant } \\
\text { ized le } \\
\text { ident va }\end{array}$ & $\begin{array}{l}\text { Le } r \text { is } \\
\text { the Unit } \\
\text { migrate } \\
\text { that r } \\
\text { squares } \\
\text { le. Th }\end{array}$ & $\begin{array}{l}\text { to } \\
\text { tates: } \\
\text { the } \\
\text { ned to } \\
\text { imator }\end{array}$ \\
\hline
\end{tabular}




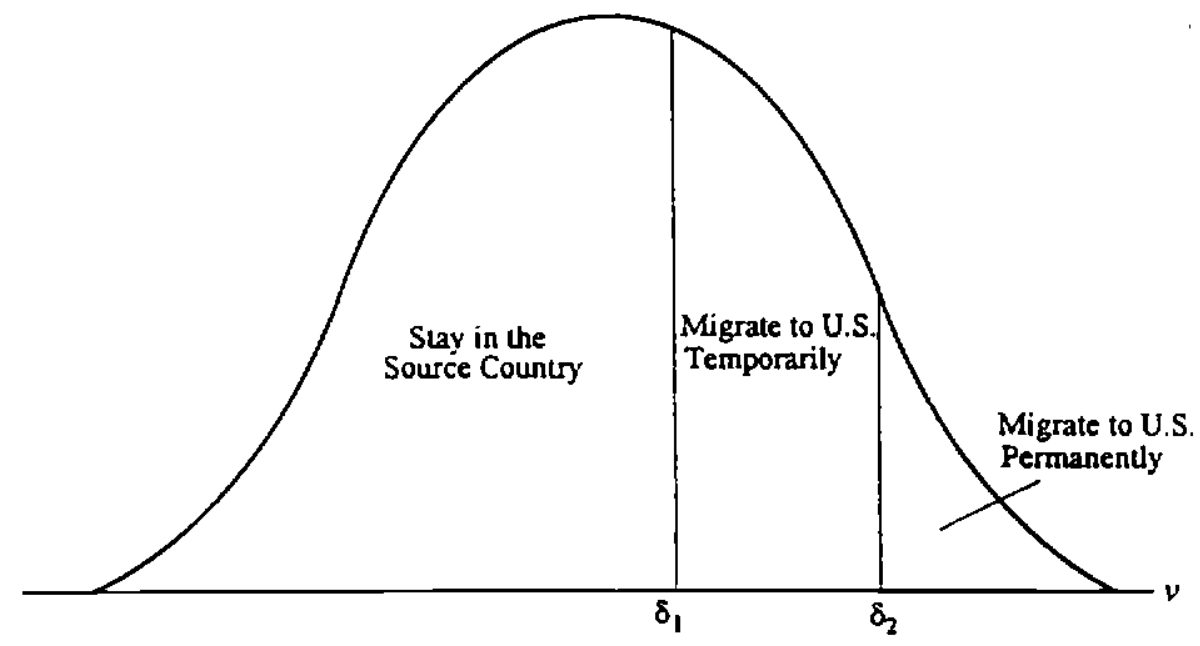

Figure 1. Skill Sorting in Human Capital Model when $\eta<1$. 


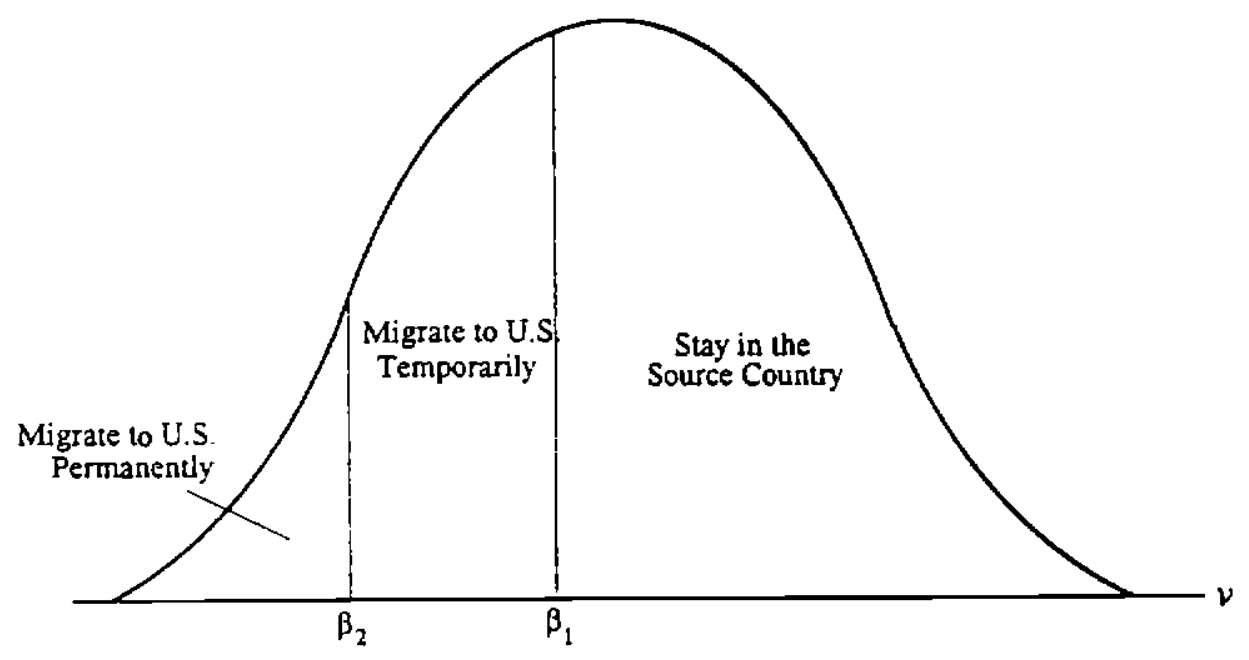

Figure 2. Skill Sorting in Human Capital Model when $\eta>1$. 


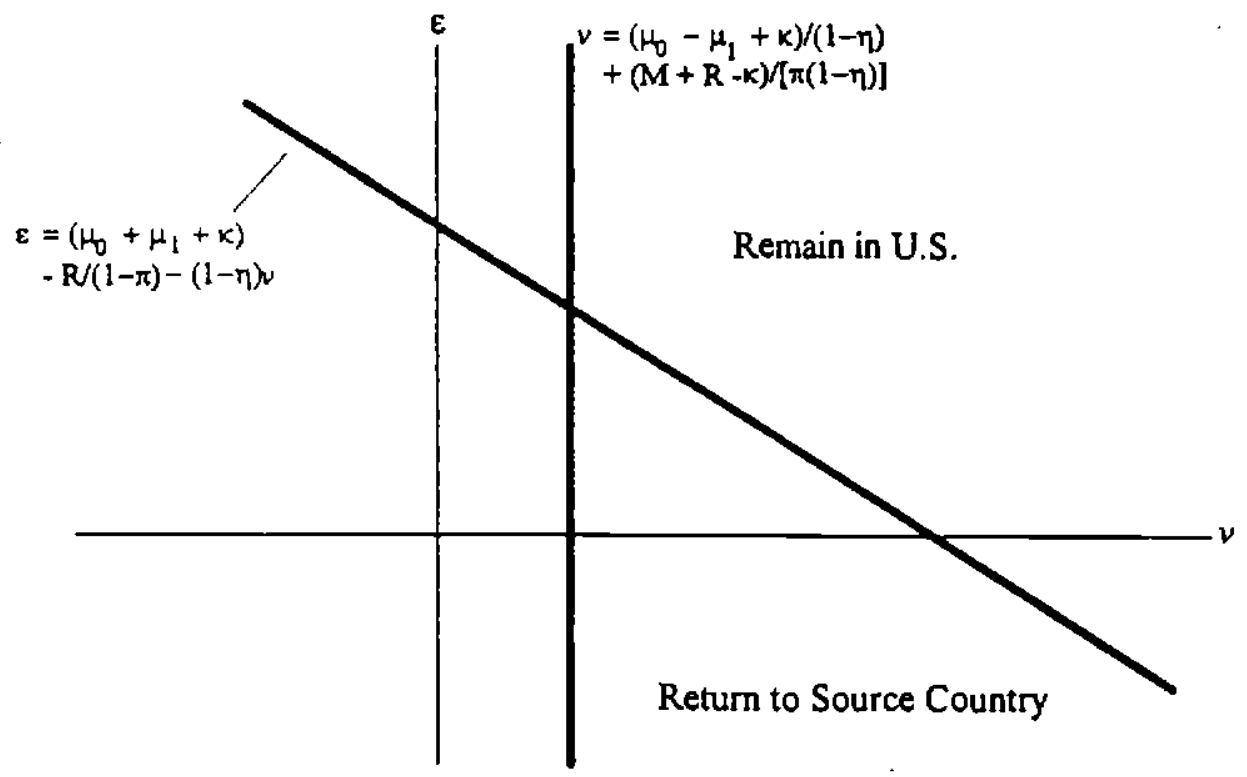

Figure A-1. Skill Sorting in Uncertainty Model when $\eta<1$ 


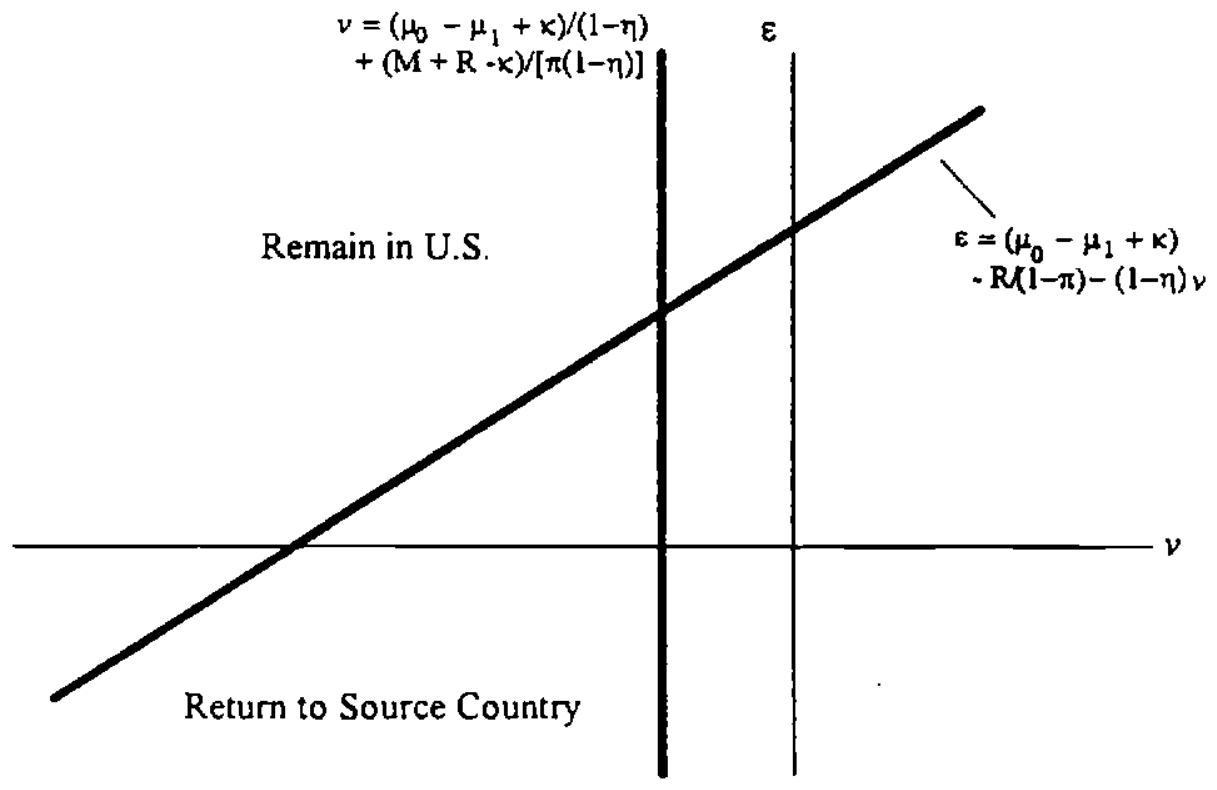

Figure A-2. Skill Sorting in Uncertainty Model when $\eta<1$ 
To order any of these papers, see instructions at the end of the list. To subscribe to all NBER Working Papers or the papers in a single area, see instructions inside the back cover. A complete list of NBER Working Papers and Reprints can be accessed on the Internet by using our gopher at nber.harvard.edu.

\begin{tabular}{|c|c|c|c|}
\hline Number & Author(s) & $\underline{\text { Title }}$ & Dale \\
\hline 4871 & Lars E. O. Svensson & $\begin{array}{l}\text { Estimating and Interpreting Forward } \\
\text { Interest Rales: Sweden 1992-1994 }\end{array}$ & 9/94 \\
\hline 4872 & George J. Borjas & Immigration and Welfare. $1970-1990$ & $9 / 94$ \\
\hline 4873 & $\begin{array}{l}\text { José De Gregorio } \\
\text { Federico Sturzenegger }\end{array}$ & $\begin{array}{l}\text { Credit Markets and the Welfare Costs } \\
\text { of Inflation }\end{array}$ & $10 / 94$ \\
\hline 4874 & $\begin{array}{l}\text { Brandice J. Canes } \\
\text { Harvey S. Rosen }\end{array}$ & $\begin{array}{l}\text { Following in Her Footsteps? Women's Choices } \\
\text { of College Majors and Faculty Gender Composition }\end{array}$ & $10 / 94$ \\
\hline 4875 & $\begin{array}{l}\text { Raghuram G. Rajan } \\
\text { Luigi Zingales }\end{array}$ & $\begin{array}{l}\text { What Do We Know about Capital Structure? } \\
\text { Some Evidence from International Data }\end{array}$ & $10 / 94$ \\
\hline 4876 & $\begin{array}{l}\text { Gene Grossman } \\
\text { Elhanan Helpman }\end{array}$ & Foreign Investment with Endogenous Protection & $10 / 94$ \\
\hline 4877 & $\begin{array}{l}\text { Gene Grossman } \\
\text { Elhanan Helpman }\end{array}$ & $\begin{array}{l}\text { Electoral Competition and Special Inlerest } \\
\text { Politics }\end{array}$ & $10 / 94$ \\
\hline 4878 & $\begin{array}{l}\text { C. Kcith Head } \\
\text { John C. Ries } \\
\text { Deborah L. Swenson }\end{array}$ & $\begin{array}{l}\text { The Attraction of Foreign Manufacturing } \\
\text { Investments: Investment Promotion and } \\
\text { Agglomeration Economies }\end{array}$ & $10 / 94$ \\
\hline 4879 & David M. Cutler & Market Failure in Small Group Health Insurance & $10 / 94$ \\
\hline 4880 & $\begin{array}{l}\text { Douglas Holtz-Eakin } \\
\text { John R. Penrod } \\
\text { Harvey S. Rosen }\end{array}$ & $\begin{array}{l}\text { Health Insurance and the Supply of } \\
\text { Entrepreneurs }\end{array}$ & $10 / 94$ \\
\hline 4881 & $\begin{array}{l}\text { Nouriel Roubini } \\
\text { Gian Maria Milesi-Ferretti }\end{array}$ & $\begin{array}{l}\text { Taxation and Endogenous Growth in Open } \\
\text { Economies }\end{array}$ & $10 / 94$ \\
\hline 4882 & $\begin{array}{l}\text { Nouriel Roubini } \\
\text { Gian Maria Milesi-Ferretti }\end{array}$ & $\begin{array}{l}\text { Optimal Taxation of Human and Physical Capital } \\
\text { in Endogenous Growth Models }\end{array}$ & $10 / 94$ \\
\hline 4883 & $\begin{array}{l}\text { Raquel Fernandez } \\
\text { Richard Rogerson }\end{array}$ & $\begin{array}{l}\text { Public Education and Income Distribution: A } \\
\text { Quantitative Evaluation of Education Finance Refom }\end{array}$ & $10 / 94$ \\
\hline 4884 & $\begin{array}{l}\text { R. Glenn Hubbard } \\
\text { Jonachan Skinner } \\
\text { Stephen P. Zeldes }\end{array}$ & Precautionary Saving and Social Insurance & $10 / 94$ \\
\hline 4885 & Martin Feldstein & Fiscal Policies, Capital Formation and Capitalism & $10 / 94$ \\
\hline 4886 & $\begin{array}{l}\text { Oliver Hart } \\
\text { John Moore }\end{array}$ & $\begin{array}{l}\text { Debt and Seniority: An Analysis of the Role } \\
\text { of Hard Claims in Constraining Management }\end{array}$ & $10 / 94$ \\
\hline
\end{tabular}


To order any of these papers, see instructions at the end of the list. To subscribe to all NBER Working Papers or the papers in a single area, see instructions inside the back cover. A complete list of NBER Working Papers and Reprints can be accessed on the Internet by using our gopher at nber.harvard.edu.

\begin{tabular}{|c|c|}
\hline Number & Author(s) \\
\hline 4887 & $\begin{array}{l}\text { Ricardo J. Caballero } \\
\text { Eduardo M.R.A. Engel }\end{array}$ \\
\hline 4888 & $\begin{array}{l}\text { Martin Feldstein } \\
\text { James H. Stock }\end{array}$ \\
\hline 4889 & $\begin{array}{l}\text { Mark Hooker } \\
\text { Michael Knelter }\end{array}$ \\
\hline 4890 & $\begin{array}{l}\text { John R. Graham } \\
\text { Campbell R. Harvcy }\end{array}$ \\
\hline 4891 & W. Kip Viscusi \\
\hline 4892 & Alan M. Taylor \\
\hline 4893 & $\begin{array}{l}\text { Maurice Obsifeld } \\
\text { Kenneth Rogoff }\end{array}$ \\
\hline 4894 & Michatel M. Kneller \\
\hline 4895 & Peter Diamond \\
\hline 4896 & Lawrence H. Goulder \\
\hline
\end{tabular}

\section{Title}

Dace

Explaining Investment Dynamics in U.S. Manufacturing: A Generalized $(S, S)$ Approach

Measuring Money Growth When Financial Markets Are Changing

Unemployment Effects of Military Spending: Evidence from a Panel of States

Market Timing Ability and Volatility Implied in Investment Newsletters' Asset Allocation Recommendations

Cigarcite Taxation and the Social Consequences of Smoking

Domestic Saving and International Capital Flows Reconsidered

The Intertemporal Approach to the Current Account

Why Are Relail Prices in Japan So High?: Evidence from German Export Prices

Insulation of Pensions from Political Risk

Environmental Taxation and the "Double Dividend": A Reader's Guide

Optimal Environmental Taxation in the Presence of Oher Taxes: General Equilibrium Analyses

Speculative Altacks on Pegged Exchange Rates: An Empirical Exploration with Special Reference to the European Monetary System

From Superminis to Supercomputers: Estimating Surplus in the Computing Market

IRAs and Household Saving Revisited: Some New Evidence

The Compctitive Crash in Large-Scale Commercial Computing
$10 / 94$

$10 / 94$

$10 / 94$

$10 / 94$

$10 / 94$

$10 / 94$

$10 / 94$

$10 / 94$

$10 / 94$

$10 / 94$

$10 / 94$

$10 / 94$

$10 / 94$

$10 / 94$

$10 / 94$ 
To order any of these papers, see instructions at the end of the list. To subscribe to all NBER Working Papers or the papers in a single area, see instructions inside the back cover. A complete list of NBER Working Papers and Reprints can be accessed on the Internet by using our gopber at nber.harvard.edu.

\begin{tabular}{|c|c|c|c|}
\hline Number & Author(s) & Tille & Date \\
\hline 4902 & Joel Slemrod & Free Trade Taxation and Protectionist Taxation & 10,94 \\
\hline 4903 & $\begin{array}{l}\text { Assaf Razin } \\
\text { Efraim Sadka }\end{array}$ & $\begin{array}{l}\text { Resisting Migration: The Problems of Wage } \\
\text { Rigidity and the Social Burden }\end{array}$ & $10 / 94$ \\
\hline 4904 & $\begin{array}{l}\text { Emst R. Berndt } \\
\text { Linda Bui } \\
\text { David Reiley } \\
\text { Glen Usban }\end{array}$ & $\begin{array}{l}\text { The Roles of Marketing. Product Quality and } \\
\text { Price Competition in the Growth and } \\
\text { Composition of the U.S. Anti-Ulicer } \\
\text { Drug Industry }\end{array}$ & $10 / 94$ \\
\hline 4905 & $\begin{array}{l}\text { Thomas C. Kinnaman } \\
\text { Don Fullerton }\end{array}$ & $\begin{array}{l}\text { How a Fee Per-Unit Garbage Affects } \\
\text { Aggregate Recycling in a Model with } \\
\text { Heterogeneous Households }\end{array}$ & 10,94 \\
\hline 4906 & Daniel S. Hamermesh & $\begin{array}{l}\text { Aging and Produclivity. Rationality and } \\
\text { Matching: Evidence from Economists }\end{array}$ & $10 / 94$ \\
\hline 4907 & $\begin{array}{l}\text { Kooyul Jung } \\
\text { Yong-Cheol Kim } \\
\text { René M. Stulz }\end{array}$ & $\begin{array}{l}\text { Investment Opportunities, Managerial } \\
\text { Discretion, and the Security Issue } \\
\text { Decision }\end{array}$ & $10 / 94$ \\
\hline 4908 & $\begin{array}{l}\text { Jun-Koo Kang } \\
\text { Rene M: Stulz }\end{array}$ & $\begin{array}{l}\text { How Different is Japanese Corporate } \\
\text { Finance? An Investigation of the } \\
\text { Information Content of New Security Issues }\end{array}$ & $10 / 94$ \\
\hline 4909 & Robert J. Barro & Democracy and Growth & $10 / 94$ \\
\hline 4910 & Richard B. Freeman & Crime and the Job Market & $10 / 94$ \\
\hline 4911 & Rebecca M. Blank & The Dynamics of Part-Time Work & $11 / 94$ \\
\hline 4912 & George J. Borjas & $\begin{array}{l}\text { Ethnicity, Neighborhoods, and Human Capital } \\
\text { Externalities }\end{array}$ & $11 / 94$ \\
\hline 4913 & $\begin{array}{l}\text { George J. Borjas } \\
\text { Bemt Bratsberg }\end{array}$ & $\begin{array}{l}\text { Who Leaves? The Oulmigration of the } \\
\text { Foreign-Born }\end{array}$ & $11 / 94$ \\
\hline
\end{tabular}

Copies of the above working papers can be obtained by sending $\$ 5.00$ per copy (plus $\$ 10.00$ per order for postage and handling for all locations outside the continental U.S.) to Working Papers. NBER, 1050 Massachusetts Avenue, Cambridge, MA 02138-5398. Advance payment is required on all orders. Payment may be made by check or credit card. Checks should be made payable to the NBER and must be in dollars drawn on a U.S. bank. If paying by credit card, include the cardholder's name, account number and expiration date. For all mail orders, please be sure to include your return address and telephone number. Working papers may also be ordered by telephone $(617-868-3900)$, or by fax (617-868-2742). 


\section{National Bureau of Economic Research}

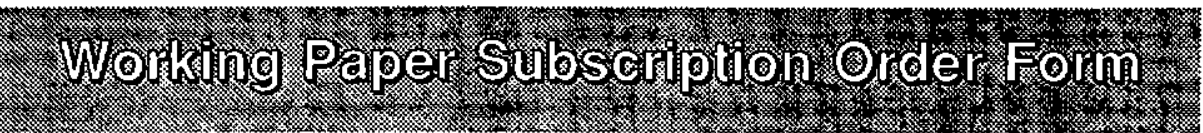

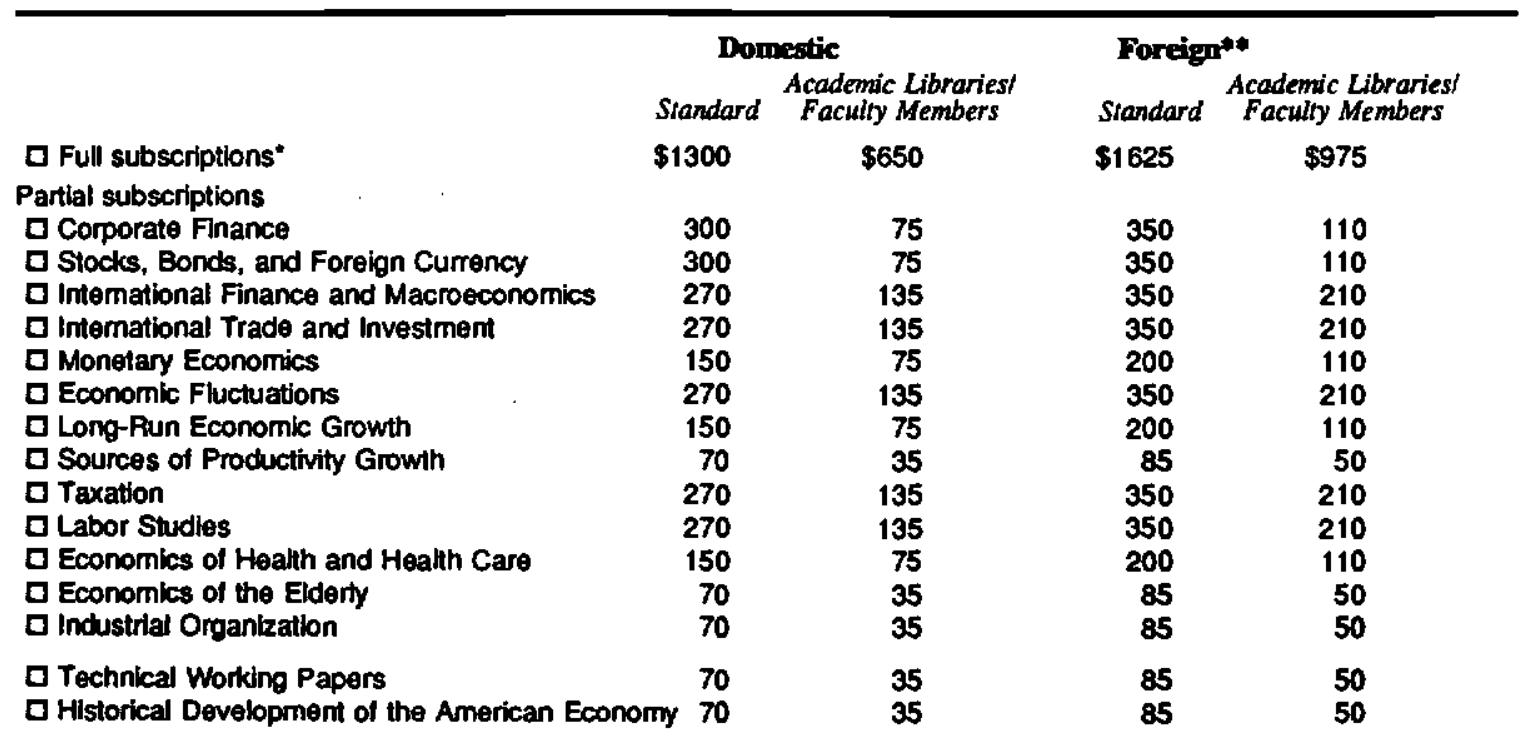

- A full subscription includes all topics listed under "partial subscriptions" except for Technical Working Papers and papers on the Historical Development of the American Economy. These must be ordered in addition to the full subscription.

* Please Inquire about subscription prices for Arrica and Australia.

\section{PAYMENT OPTIONS}

YES! Please begin my subscription to the NBER Working Paper Series. I have indicated above which papers I would like to recelve.

By Phone: (617) 868-3900

By FAX: (617) 868-2742

By Mail: Publications Department

Publications Department 1050 Massachusetts Ave. Cambridge, MA 02138

$\checkmark$ Payment in the amount of enclosed.

$\square$ Please charge my: $\square$ VISA $\square$ MasterCard

Cand Number:

Card expiration:

Signature:
Please mail my papers to this address:

Name

Address

Phone:

FAX: 